\title{
Butyrate Enemas Upregulate $M u c$ Genes Expression but Decrease Adherent Mucus Thickness in Mice Colon
}

\author{
E. GAUDIER, M. RIVAL, M.-P. BUISINE ${ }^{1}$, I. ROBINEAU, C. HOEBLER \\ Unité Mixte de Recherche de Physiologie des Adaptations Nutritionnelles, Institut National de la \\ Recherche Agronomique / Université de Nantes, Centre de Recherche en Nutrition Humaine, \\ Nantes and ${ }^{1}$ Inserm, U837 Jean Pierre Aubert Research Center, Lille, France
}

Received April 18, 2007

Accepted October 18, 2007

On-line January 17, 2008

\begin{abstract}
Summary
Colonic mucosal protection is provided by the mucus gel, mainly composed of mucins. Several factors can modulate the formation and the secretion of mucins, and among them butyrate, an endproduct of carbohydrate fermentation. However, the specific effect of butyrate on the various colonic mucins, and the consequences in terms of the mucus layer thickness are not known. Our aim was to determine whether butyrate modulates colonic MUC genes expression in vivo and whether this results in changes in mucus synthesis and mucus layer thickness. Mice received daily for 7 days rectal enemas of butyrate (100 mM) versus saline. We demonstrated that butyrate stimulated the gene expression of both secreted (Muc2) and membrane-linked (Muc1, Muc3, Muc4) mucins. Butyrate especially induced a 6-fold increase in Muc2 gene expression in proximal colon. However, butyrate enemas did not modify the number of epithelial cells containing the protein Muc2, and caused a 2-fold decrease in the thickness of adherent mucus layer. Further studies should help understanding whether this last phenomenon, i.e. the decrease in adherent mucus gel thickness, results in a diminished protective function or not.
\end{abstract}

\section{Key words}

Mucus • Mucin • Butyrate $\bullet$ Colon • Mice

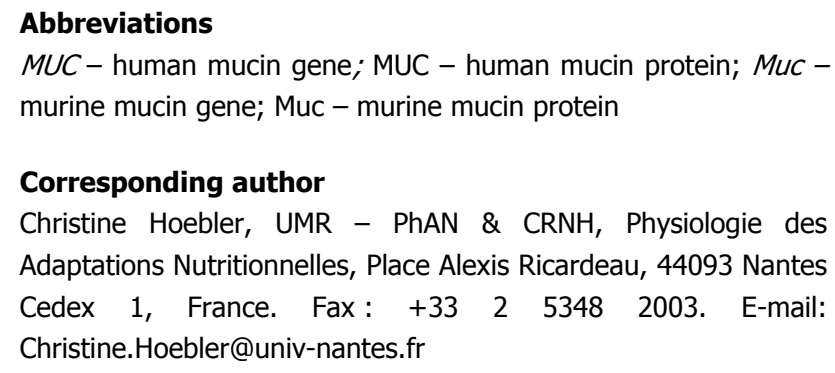

\section{Introduction}

The mucus layer, covering the gastrointestinal mucosa, is considered as the first line of defense against mechanical, chemical, or microbiological aggressions arising from the luminal contents (Corfield et al. 2000). Indeed, the break of the mucus barrier in inflamed colon has been shown to allow bacterial adherence to epithelial tissue (Swidsinski et al. 2007), and the removal of the mucus layer favors the penetration of high molecular weight probes in mucosa (Iiboshi et al. 1996, Khan et al. 1999). In the colon, the mucus is mainly composed of the secreted mucin called MUC2, but other membrane-bound mucins are also expressed: mainly MUC1, MUC3 and MUC4 (Carraway et al. 2003). The specific functions of various mucins are still unclear, but they appear to have other functions than only gel-forming. For example, it has been shown that Muc2 deficiency leads to inflammation of the colon and contributes to the onset and perpetuation of experimental colitis (Van der Sluis et al. 2006). In addition, membrane-linked mucins, like MUC1 (Leroy et al. 2006) and MUC4 (Rong et al. 2005), exhibit specific functions in adhesion and cell signaling (Carraway et al. 2003), and could take a crucial part in maintaining the integrity of the colonic barrier.

In the colon, the mucus layer is directly in contact with the short chain fatty acids (SCFA) produced by fermentation of indigestible carbohydrates by the resident microflora. These SCFA (mainly acetate, propionate and butyrate) are known to affect the colonic mucosa; more specifically, butyrate constitutes the major energy source for colonocytes (Roediger 1982); it is able 
to modulate both the epithelial cell proliferation (Blottiere et al. 2003) and the intestinal immunity (Segain et al. 2000), and thus plays a central role for colonic health (Roy et al. 2006). However, the specific impact of butyrate has been studied only on the mucus layer and not on $M u c$ gene expression (Kleessen et al. 2003). SCFA, infused in colonic loop, have been shown to stimulate mucin discharge in rats colon (Shimotoyodome et al. 2000), and butyrate appeared to be the most effective SCFA in modulating mucin production and release in vivo (Barcelo et al. 2000, Finnie et al. 1995, Shimotoyodome et al. 2000). In addition, butyrate could modulate mucin expression in vitro in human colonic cell lines both at the gene and protein level (Augenlicht et al. 2003, Gaudier et al. 2004, Willemsen et al. 2003). But in all of these studies, Muc gene expression and mucin production were never related to the mucus layer, although the mucus layer thickness is considered as a main protective parameter of intestinal epithelium. Butyrate-producing carbohydrate fermentation was shown to increase the mucus layer thickness (Kleessen et al. 2003), but in these experiments, it was not possible to discriminate the effects of butyrate production from the effects of the modifications in the colonic microflora that also take place during carbohydrate fermentation.

The aim of this study was to determine the effect of repeated instillation of butyrate in vivo on the expression of the different colonic mucins, and to relate it to possible modifications of the mucus layer thickness, which could result in a benefit for the colonic mucosa.

\section{Methods}

Animals

Male BALB/c mice (Janvier, Le Genest Saint Isle, France), 8 weeks of age, with an initial mean weight of $22.8 \pm 0.2 \mathrm{~g}$, were randomly housed by groups of six mice per cage, and maintained at $23{ }^{\circ} \mathrm{C}$ in an animal room with a $12 \mathrm{~h}$ light: dark cycle (light: 0700-1900 h). Food and water were consumed ad libitum. The diet followed AIN-93G standard formula (Reeves et al. 1993) (INRA, Jouy-en-Josas, France). Body weight gain, food and water consumption were assessed every day in the course of experiment. All experiments were carried out in accordance with the recommendations of the local Animal Care and Use Committee of Nantes (France).

\section{Treatment with butyrate enemas}

At day 0, mice were randomly split in two groups ( $\mathrm{n}=20$ each) named control versus butyratetreated. Every morning from day 0 to day 6 , mice were mildly anesthetized by intramuscular injection of $60 \mu \mathrm{l}$ of a mixture of $5 \mathrm{mg} / \mathrm{ml}$ of ketamin (Mérial, Lyon, France) and $5 \mathrm{mg} / \mathrm{ml}$ of zolethyl (Virbac, Carros, France). $5 \mathrm{~min}$ after anesthesia, mice received rectal instillation of $100 \mu \mathrm{l}$ of saline or $100 \mathrm{mM}$ butyrate (Sigma, Saint QuentinFallavier, France) by $2.4 \mathrm{~cm}$ steel cannula for control mice or butyrate-treated mice, respectively. Both solutions were adjusted to $\mathrm{pH} 6.5$ and osmolarity 295 mosmol/l. Mice were kept in a vertical position head upside down for $10 \mathrm{~min}$ before returning to their cages, to avoid excretion of the enema solution.

\section{Collection of digestive tissues and contents}

At the end of 7-day experimental period, i.e. $24 \mathrm{~h}$ after the last butyrate instillation, the animals were killed by cervical dislocation. The colon length was first measured in a relaxed position without stretching. The proximal and distal colons were then removed; the split between proximal and distal colon was set at the half length of the colon. Colonic contents were aseptically collected and immediately used for SCFA concentration assessment ( $\mathrm{n}=10$ per group). Proximal and distal colonic tissues were carefully longitudinally opened and cleaned with sterile physiological serum. They were immediately frozen with $1 \mathrm{ml}$ of Trizol (Invitrogen Life Technologies, Cergy-Pontoise, France) in liquid nitrogen and stored at $-70{ }^{\circ} \mathrm{C}$ for RNA isolation ( $\mathrm{n}=10$ per group), or fixed in $4 \%$ formaldehyde in Dulbecco's phosphate buffered saline (Sigma), dehydrated and paraffin-embedded for histological observations ( $\mathrm{n}=10$ per group). In order to measure mucus layer thickness, small segments with their contents ( $\mathrm{n}=10$ per group) were taken from the distal colon about $1 \mathrm{~cm}$ proximal to the anus, frozen in liquid nitrogen and stored at $-70^{\circ} \mathrm{C}$.

\section{SCFA analysis}

Contents of proximal and distal colon were collected for SCFA analysis. After centrifugation of thawed samples $(8000 \times g$ for $10 \mathrm{~min})$, the supernatants were supplemented with $0.9 \mathrm{ml}$ of oxalic acid $(0.5 \mathrm{M})$ (Schafer 1995). SCFA were analyzed by capillary gasliquid chromatography (SGE BP21 capillary column: $25 \mathrm{~m} \times 0.53 \mathrm{~mm}$, nitrogen as carrier gas: $17 \mathrm{ml} / \mathrm{min}$ ). The injector and detector temperature was maintained at $250{ }^{\circ} \mathrm{C}$ and $200{ }^{\circ} \mathrm{C}$, respectively, the oven temperature at $90{ }^{\circ} \mathrm{C}$. Samples $(1 \mu \mathrm{l})$ was introduced by splitless injection, with a split flow $50 \mathrm{ml} / \mathrm{min}$ beginning $1 \mathrm{~min}$ 
after injection. The concentration of butyrate was determined by comparing to a known concentration of butyrate solution (from $0.2 \mathrm{mM}$ to $2 \mathrm{mM}$ ) analyzed in the same chromatographic conditions.

\section{Quantification of mucin gene expression by RT-PCR}

Total RNA of proximal and distal colon tissues was isolated by Trizol extraction and submitted to reverse transcription as previously described (Hoebler et al. 2006). The amplification was performed with QuantiTect SYBR Green PCR Kit (Qiagen, Courtaboeuf, France), using the following time and temperature profile: i) $95^{\circ} \mathrm{C}$ for $5 \mathrm{~min}$, ii) 45 cycles of $1 \mathrm{~min}$ at $95^{\circ} \mathrm{C}, 10 \mathrm{~s}$ at $60^{\circ} \mathrm{C}$, $10 \mathrm{~s}$ at $72{ }^{\circ} \mathrm{C}$, and iii) a final extension at $72{ }^{\circ} \mathrm{C}$. The sequences of the primers used for Muc1, Muc2, Muc3, and Muc4 gene amplification have been previously indicated (Hoebler et al. 2006). Gene expressions in each segment of butyrate-treated mice were expressed by using calibrator gene $(18 \mathrm{~s})$ and as relative values compared to values of saline-treated mice.

Analysis of Muc2 protein expression by immunohistochemistry

The staining procedure was conducted using an automated immunostainer (ES, Ventana Medical Systems, Strasbourg, France) and a three-step indirect process based on the biotin-streptavidin-peroxidase method. Tissue sections $(8 \mu \mathrm{m})$ were deparaffinized with xylene (Merck, Darmstadt, Germany) and rehydrated in graded ethanol solutions. After pressure cooker pretreatment in citrate buffer $(\mathrm{pH} 6.0)$ for $1 \mathrm{~min} 30$, tissue sections were incubated for $20 \mathrm{~min}$ with fresh $3 \%$ hydrogen peroxide in methanol to block endogenous peroxidase. Sections were then treated with periodic acid (20 $\mathrm{mM}$ in sodium acetate $0.05 \mathrm{M}, \mathrm{pH} 5.0$ ) for $30 \mathrm{~min}$ and with glycine $1 \%$ for $30 \mathrm{~s}$ to destroy glycotopes containing $\mathrm{N}$-acetylgalactosamine or fucose as previously described (Bara et al. 1992, Cao et al. 1997). All sections were incubated for $32 \mathrm{~min}$ at $37{ }^{\circ} \mathrm{C}$ with the primary antibody anti-Muc2 (1/20) (Muc2 goat polyclonal IgG, Santa Cruz Biotechnology, California, USA). After washing, the sections were incubated with the biotinylated secondary antibody (1/500) (Biotin-SPconjugated AffiniPure Donkey anti-goat IgG, Jackson ImmunoResearch Laboratories, Soham, UK) for $8 \mathrm{~min}$ at $37{ }^{\circ} \mathrm{C}$, with streptavidine-peroxidase conjugate, and then developed with diaminobenzidine (Sigma) in $0.03 \%$ hydrogen peroxide. Sections were then counterstained using hematoxylin and observed under Nikon microscope. For quantitative analysis of Muc2-positive cells, ten crypts were chosen in well-oriented sections of caecum, proximal and distal colonic sections of mice as previously described (Verburg et al. 2000). The number of Muc2-positive cells found in proximal colon and distal colon of control mice and butyrate-treated mice were compared.

Histological morphometry of adherent mucus thickness in distal colon

For the measurement of mucus layer thickness, transverse sections $(20 \mu \mathrm{m})$ of frozen distal colon including pellets were cut with a cryostat (Microm HM 500 OM, Carl Zeiss, Oberkochen, Germany) and fixed on SuperFrost Plus Gold slides (Menzel-Glaser, Braunschweig, Germany) (Szentkuti and Lorenz 1995). Sections were stained with AB pH 2.5-PAS (Jordan et al. 1998). Microscope images (Nikon, Japan) of the stained sections were analyzed with Lucia software (Laboratory Imaging Ltd, Prague, Czech Republic). The adherent mucus layer thickness was measured at five points of the circumference of six different sections for each mouse. The mean of these thirty measurements was considered as the adherent mucus thickness for each mouse.

\section{Statistical analysis}

Statistical analysis was performed using the Statview 5.0 package (SAS Institute, Berkeley, CA). Student T-test was used to assess the effects of butyrate enemas versus saline enemas, with differences being considered as significant if $\mathrm{P}<0.05$. Data are expressed as mean \pm S.E.M.

\section{Results}

\section{Effect of butyrate enema}

After 7 days of instillation of saline or butyrate, no difference was found between the two groups of mice in terms of food and water intake, as well as weight gain $(1.28 \pm 0.23 \mathrm{~g}$ in the saline group vs. $1.28 \pm 0.12 \mathrm{~g}$ in the butyrate group).

Colonic characteristics were also not different between the 2 groups: colon length did not vary between saline- and butyrate-treated mice $(9.0 \pm 0.2 \mathrm{~cm}$ and $9.2 \pm 0.2$ $\mathrm{cm}$, respectively), and SCFA amounts in the proximal colon were not affected by the rectal butyrate enema. More interestingly, SCFA concentrations in the distal contents were also not modified by the repetitive instillation of butyrate: indeed in butyrate-treated mice 


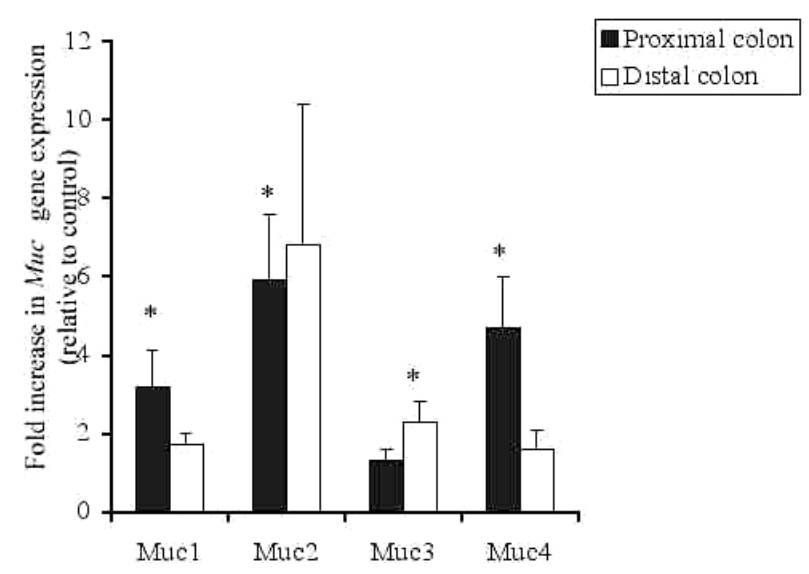

Fig 1. Muc $(1,2,3,4)$ gene expression in the proximal colon, distal colon of mice treated with saline $v s$ butyrate enemas. Total RNA was isolated from colonic tissue. The expression of Muc gene was determined by real-time quantitative PCR. Values are expressed as the relative gene expression determined in each segment of butyrate-treated mice compared to saline-treated mice. Values are means, S.E.M. ( $n=10$; significant difference by Student's $\mathrm{t}$ test, $* \mathrm{P}<0.05)$.

vs. saline treated mice, SCFA concentrations were $54 \pm 10$ vs $41 \pm 6 \mu \mathrm{mol} / \mathrm{g}$ of wet content of acetate, concentrations were $10 \pm 2$ vs $8 \pm 1 \mu \mathrm{mol} / \mathrm{g}$ of wet content of propionate and $5 \pm 1$ vs $4 \pm 1 \mu \mathrm{mol} / \mathrm{g}$ of wet content of butyrate.

\section{Quantification of Muc gene expression in colon}

In distal colon, butyrate enemas significantly increased Muc3 gene expression $(\mathrm{p}=0.011)$, and its stimulation of $\mathrm{Mucl}$ and $\mathrm{Muc2}$ gene expression was close to significance $(\mathrm{p}=0.08)$. Surprisingly, butyrate enhancing effects were greater in proximal colon than in distal colon, with three gene expressions significantly enhanced: $M u c 1, M u c 2$ and Muc4 ( $\mathrm{p}=0.020, \mathrm{p}=0.003$ and $\mathrm{p}=0.008$, respectively) (Fig. 1). If we compare the four major $M u c$ genes expressed in colon, butyrate enhanced preferentially Muc2 gene expression, with a 6-fold increase and then Muc4 gene expression, with 4.7-fold increase, both in the proximal colon. Mucl gene expression was enhanced by butyrate mainly in the proximal colon by a marked factor of 3.2, and Muc3 gene expression was stimulated by butyrate only in the distal colon, by a moderate factor of 2.3 .

Evaluation of Muc2 protein expression by immunohistochemistry

Butyrate enemas caused no significant change in the number of Muc2-positive cells in mucosal crypts in both proximal and distal colon (Table 1, Fig. 2), but we can not assess that there was no changes in Muc2 protein.
Table 1. Number of Muc2-positive cells per crypt (immunohistochemistry) in the colon of mice who received saline enema versus butyrate enemas

\begin{tabular}{lccc}
\hline & Saline & Butyrate & $\begin{array}{c}\text { Student's } \\
\text { T test }\end{array}$ \\
\hline Proximal colon & $4.8 \pm 1.7$ & $3.8 \pm 2.2$ & NS \\
Distal colon & $4.3 \pm 1.3$ & $4.1 \pm 1.0$ & NS \\
\hline
\end{tabular}

Data are means \pm S.E.M. $(n=10)$.

Assessment of adherent mucus thickness in distal colon.

Butyrate enemas caused a significant 2.5-fold decrease in adherent mucus thickness in distal colon $(12 \pm 3 \mu \mathrm{m})$, in comparison with saline enemas $(30 \pm 2 \mu \mathrm{m})$ $(\mathrm{p}=0.0001)$ (Fig. 3).

\section{Discussion}

The increase of $M U C$ gene expression induced by butyrate has been always evaluated in in vitro conditions with colon cancer cell line (Augenlicht et al. 2003, Gaudier et al. 2004, Hatayama et al. 2007). Moreover, the mucus layer of distal colon has been already shown to be increased by the fermentation of indigestible carbohydrate producing high concentration of butyrate (Kleessen et al. 2003). The aim of this work was to evaluate the specific in vivo effect of butyrate on colonic mucin gene expression, and to relate it to the mucus layer thickness in mice.

We have chosen to administrate butyrate through rectal enemas, because it allowed a repeated administration of butyrate for several days. The enema method has the disadvantage to inject free water in the distal colon, but the volume of instillation was low $(100 \mu \mathrm{l})$ and we did not observe any diarrhea in both groups of animals (butyrate vs. saline), which supports the absence of major intestinal disturbance. We checked with an alcian-blue dye that the enema solution reached the whole distal colon. However, as it was impossible to control the diffusion of butyrate in colonic contents, we analyzed the effect on mucin production in both proximal and distal segments. We chose to use a $100 \mathrm{mM}$ butyrate solution, because similar concentrations were used in rats studies demonstrating a stimulation of mucin secretion by butyrate (Barcelo et al. 2000, Shimotoyodome et al. 2000). This butyrate concentration is relatively high in comparison to what was measured in colonic content ( $5 \mathrm{~mol} / \mathrm{g}$ of wet content). But, it is known that butyrate is rapidly absorbed by the mucosa (Roediger 1982) and that the concentration determined in 


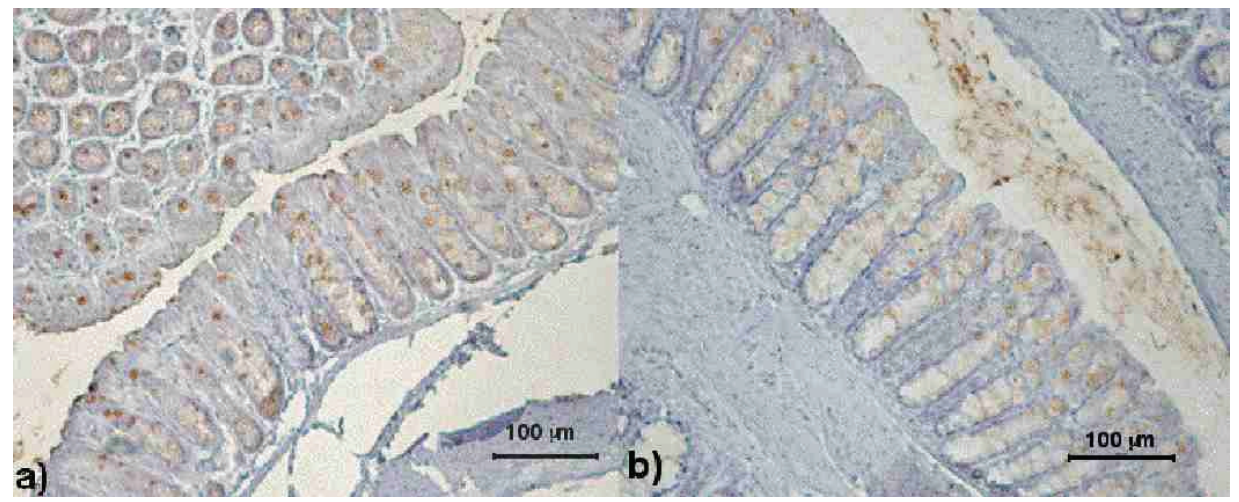

Fig. 2. Goblet cell-specific expression of Muc2 in the distal colon of mice treated with saline (a) versus butyrate enemas $(b)$. Muc2 staining was performed on paraffin-embedded sections using an anti-Muc2 polyclonal antibody (Santa Cruz Biotech), hematoxylin as counterstained. Original magnification: $\mathrm{x} 20$.
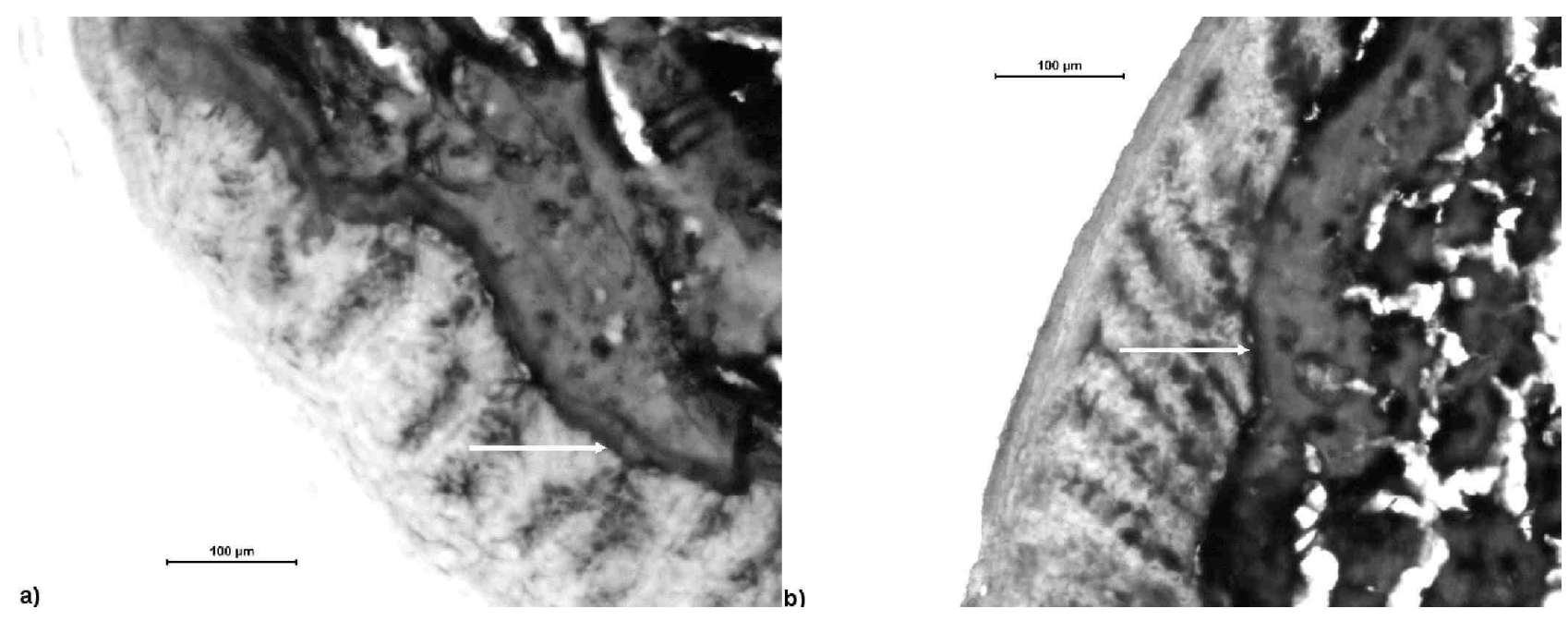

Fig. 3. PAS-Alcian blue stained sections of distal colon of mice treated with saline (a) vs. butyrate (b) enemas. White arrows point out the adherent mucus layer. Bar $=100 \mu \mathrm{m}$. Original magnification: X20.

contents is estimated to correspond only to a weak part of the total amount produced during the fermentation (Mortensen and Clausen 1996). The fact that we do not recover an extra amount of butyrate in colonic contents 24 $\mathrm{h}$ after enemas suggests that the instilled dose of butyrate was low enough to be fully absorbed by the mucosa.

We demonstrated for the first time in vivo that butyrate affects differently the expression of various colonic mucins. Gene expression of the secreted mucin $M u c 2$ was increased to the highest extent (6-fold) in the colon. Among membrane-linked mucins, Mucl and Muc4 gene expression was significantly stimulated mainly in proximal colon, while $M u c 3$ had the expression slightly enhanced in distal colon. As butyrate is well known to be able to modulate proliferation and differentiation of colonocytes (Frankel et al. 1994), it can be wondered whether its effects on mucin gene expression are simply resulting from such effects on the colonic epithelium. First, our results concerning $M u c$ gene upregulation by butyrate cannot be attributed to a stimulation in cell proliferation because we quantified Muc gene expression in comparison with 18s RNA, which allows to assess the level of Muc mRNA independently of the number of cells. Second, the distinct effect of butyrate on the secreted Muc2 (expressed only in goblet cells) vs. the membrane-bound Muc1, Muc3 and Muc4 (expressed in both goblet cells and absorptive cells) could be due to selective stimulation of the differentiation into goblets cells. However, our immunohistochemistry results showed that butyrate enema did not increase the number of Muc2-positive goblet-cells per crypt. So we can interpret our results as an increase in the mucin gene expression per cell by butyrate, which is in accordance with previous in vitro results showing effects of butyrate on MUC gene expression (Gaudier et al. 2004, Hatayama et al. 2007).

Another striking result of our study was that the stimulation of mucin gene expression by butyrate was seen not only at the site of instillation (distal colon), but also in the proximal colon. Remote effect of butyrate has been shown for several functions (tropic effect, intestinal motility, gastric tonus) through enteric nervous system and hormonal mediation (Frankel et al. 1994, Ropert et 
al. 1996). Moreover, it is known that the stimulation of mucus secretion is also mediated by enteric nervous system, enterodocrine cells and mediators of the immune system (Plaisancie et al. 1998). Thus, we can assume that local and remote stimulation of mucin secretion by butyrate probably operate at the same time, but the proportion of neurally-mediated indirect stimulation vs. direct stimulation is so far unknown.

However, the main question raised by our study is whether the striking stimulation of Muc2 gene expression by butyrate results in changes in the mucus layer and its protective functions. Regarding our absolute values of mucus layer thickness, it has to be mentioned that the histochemistry method can only measure the adherent mucus thickness and our values $(30 \mu \mathrm{m})$ are similar to those found in distal colon of rats $(30 \pm 15 \mu \mathrm{m})$ using the same histochemical method (Szentkuti and Lorenz 1995). Other studies have found higher mucus thickness values measuring both the adherent and the total colonic mucus layer in rat after overnight fasting and using in vivo system (micropipette technique and intravital microscopy) (Atuma et al. 2001, Brownlee et al. 2003). The observed upregulation of mucin gene expression caused by butyrate in vivo is consistent with the increase in mucin synthesis in human colonic biopsies demonstrated by Finnie et al. (1995) and the short-term effect of butyrate on the release of mucus from storage vesicles into the colonic lumen (Barcelo et al. 2000, Sakata and Setoyama 1995, Shimotoyodome et al. 2000). Surprisingly, the increase in $M u c$ gene expression induced by repeated butyrate exposures, without changing the amount of Muc2-positive cell in the colonic mucosa, resulted in a decrease about twofold of the adherent mucus thickness. These results are not in agreement with the increase of the adherent mucus gel thickness observed in the colon of rat fed diet rich in butyrate-producing indigestible carbohydrate (Kleessen et al. 2003). The major difference in this intervention is that diet supplementation in fructans not only increases the production of butyrate, but also modifies the microflora composition by selectively stimulating the growth of lactic acid bacteria (Gibson and Roberfroid 1995), which could influence $M U C$ gene expression (Mack et al. 1999) and the mucin synthesis (Caballero-Franco et al. 2007).

In our experiments, it is unclear why the stimulating effect of butyrate on $M u c$ gene expression did not lead to an increase of the adherent mucus layer thickness. Although we cannot definitively exclude that $24 \mathrm{~h}$ of delay after butyrate administration is too long and we were out of butyrate effect on mucus gel, two explanations can be raised. Firstly, the increase in mucin gene expression could be accompanied with stimulation of the mucin secretion rate, which would prevent them from stabilizing and forming a gel; the mucins would be sloughed off in the colonic contents by the transit. A second explanation could be that an increase in Muc gene expression would not lead to mucin synthesis or that an increase of mucin would also be accompanied by altered glycosylation. We previously found that the upregulation of Muc gene expression was not accompanied by marked changes in the expression of glycosyl-transferases (Gaudier et al. 2004), which could result in alterations of mucin glycosylation, leading to changes in physicochemical properties and gel-forming ability.

Finally, it can be wondered whether the decrease in the adherent mucus layer thickness caused by butyrate is detrimental or beneficial for the colonic health. It is generally accepted that the mucus layer is a physical barrier protecting the mucosa (Sakamoto et al. 2004) and it can thus be postulated that a thicker mucus is more protective to ensure efficient diffusion barrier (Iiboshi et al. 1996). But mucus layer prevents the contact with epithelium through several mechanisms, e.g. hydrophobicity of mucus layer (Lugea et al. 2000) or bacterial adherence (Vesterlund et al. 2006). In view of our present results, another mechanism can been evoked: the mucus released in the colonic lumen and sloughed off with the transit could serve as a wash out for the mucosa, could take off with itself possible toxic compounds or pathogenic microorganisms and prevent them from reaching the mucosa. It is then not excluded that an increase in secretion of soluble mucins possibly caused by butyrate could constitute a defense mechanism of the mucosa, all maintaining a stimulated gene expression and mucin production to keep a defense mucus layer.

In conclusion, this work for the first time demonstrated in vivo that butyrate differently stimulates the expression of various mucin genes in the colon. The expression of the secreted Muc2 was enhanced to the largest extend, but membrane-linked Mucl, Muc3 and Muc4 were also moderately stimulated. Surprisingly, this resulted in no change in the number of Muc2-positive cells in the ceco-colonic mucosa and in a decrease in adherent mucus gel thickness. Further studies should help understanding whether this last phenomenon, i.e. the decrease in adherent mucus gel thickness, results in a diminished protective function or not. 


\section{Conflict of Interest}

There is no conflict of interest.

\section{Acknowledgements}

The authors are grateful to G. Lecannu, G. Poupeau, A. Ketele and A. David for excellent technical assistance. This work was supported by the World Cancer Research Fund International.

\section{References}

AUGENLICHT L, SHI L, MARIADASON J, LABOISSE C, VELCICH A: Repression of MUC2 gene expression by butyrate, a physiological regulator of intestinal cell maturation. Oncogene 22: 4983-4992, 2003.

BARA J, DECAENS C, LORIDON-ROSA B, ORIOL R: Immunohistological characterization of mucin epitopes by pre-treatment of gastro-intestinal sections with periodic acid. J Immunol Methods 149: 105-113, 1992.

BARCELO A, CLAUSTRE J, MORO F, CHAYVIALlE JA, CUBER JC, PLAISANCIE P: Mucin secretion is modulated by luminal factors in the isolated vascularly perfused rat colon. Gut 46: 218-224, 2000.

BLOTTIERE HM, BUECHER B, GALMICHE JP, CHERBUT C: Molecular analysis of the effect of short-chain fatty acids on intestinal cell proliferation. Proc Nutr Soc 62: 101-106, 2003.

CABALLERO-FRANCO C, KELLER K, DE SIMONE C, CHADEE K. The VSL\#3 probiotic formula induces mucin gene expression, secretion in colonic epithelial cells. Am J Physiol 292: G315-G322, 2007.

CAO Y, BLOHM D, GHADIMI BM, STOSIEK P, XING PX, KARSTEN U: Mucins (MUC1, MUC3) of gastrointestinal, breast epithelia reveal different, heterogeneous tumor-associated aberrations in glycosylation. J Histochem Cytochem 45: 1547-1557, 1997.

CARRAWAY KL, RAMSAUER VP, HAQ B: CAROTHERS CARRAWAY CA. Cell signaling through membrane mucins. Bioessays 25: 66-71, 2003.

CORFIELD AP, MYERSCOUGH N, LONGMAN R, SYLVESTER P, ARUL S, PIGNATELLI M. Mucins, mucosal protection in the gastrointestinal tract: new prospects for mucins in the pathology of gastrointestinal disease. Gut 47: 589-594, 2000.

FINNIE IA, DWARAKANATH AD, TAYLOR BA, RHODES JM: Colonic mucin synthesis is increased by sodium butyrate. Gut 36: 93-99, 1995.

FRANKEL WL, ZHANG W, SINGH A, KLURFELD DM, DON S, SAKATA T, MODLIN I, ROMBEAU JL: Mediation of the trophic effects of short-chain fatty acids on the rat jejunum, colon. Gastroenterology 106: 375-380, 1994.

GAUDIER E, FORESTIER L, GOUYER V, HUET G, JULIEN R, HOEBLER C: Butyrate regulation of glycosylationrelated gene expression: evidence for galectin-1 upregulation in human intestinal epithelial goblet cells. Biochem Biophys Res Commun 325: 1044-1051, 2004.

GAUDIER E, JARRY A, BLOTTIERE HM, DE COPPET P, BUISINE MP, AUBERT JP, LABOISSE C, CHERBUT C, HOEBLER C: Butyrate specifically modulates MUC gene expression in intestinal epithelial goblet cells deprived of glucose. Am J Physiol 287: G1168-G1174, 2004.

GIBSON GR, ROBERFROID MB. Dietary modulation of the human colonic microbiota: introducing the concept of prebiotics. J Nutr 125: 1401-1412, 1995.

HATAYAMA H, IWASHITA J, KUWAJIMA A, ABE T: The short chain fatty acid, butyrate, stimulates MUC2 mucin production in the human colon cancer cell line, LS174T. Biochem Biophys Res Commun 356: 599-603, 2007.

HOEBLER C, GAUDIER E, DE COPPET P, RIVAL M, CHERBUT C: MUC genes are differently expressed during onset, maintenance of inflammation in dextran sodium sulfate-treated mice. Dig Dis Sci 51: 381-389, 2006.

IIBOSHI Y, NEZU R, KHAN J, CHEN K, CUI L, YOSHIDA H, WASA M, FUKUZAWA M, KAMATA S, TAKAGI $\mathrm{Y}$, OKADA A. Developmental changes in distribution of the mucous gel layer, intestinal permeability in rat small intestine. JPEN J Parenter Enteral Nutr 20: 406-411, 1996.

JORDAN N, NEWTON J, PEARSON J, ALLEN A: A novel method for the visualization of the in situ mucus layer in rat, man. Clin Sci (Colch) 95: 97-106, 1998. 
KHAN J, IIBOSHI Y, CUI L, WASA M, OKADA A: Role of intestinal mucus on the uptake of latex beads by Peyer's patches, on their transport to mesenteric lymph nodes in rats. JPEN J Parenter Enteral Nutr 23: 19-23, 1999.

KLEESSEN B, HARTMANN L, BLAUT M. Fructans in the diet cause alterations of intestinal mucosal architecture, released mucins, mucosa-associated bifidobacteria in gnotobiotic rats. Br J Nutr 89: 597-606, 2003.

LEROY X, BUISINE MP, LETEURTRE E, AUBERT S, BUOB D, PORCHET N, COPIN MC: MUC1 (EMA): a key molecule of carcinogenesis? Ann Pathol 26: 257-266, 2006.

LUGEA A, SALAS A, CASALOT J, GUARNER F, MALAGELADA JR. Surface hydrophobicity of the rat colonic mucosa is a defensive barrier against macromolecules, toxins. Gut 46: 515-521, 2000.

MACK DR, MICHAIL S, WEI S, MCDOUGALL L, HOLLINGSWORTH MA: Probiotics inhibit enteropathogenic E. coli adherence in vitro by inducing intestinal mucin gene expression. Am J Physiol 276: G941-G950, 1999.

MORTENSEN PB, CLAUSEN MR. Short-chain fatty acids in the human colon: relation to gastrointestinal health, disease. Scand J Gastroenterol Suppl 216: 132-148, 1996.

PLAISANCIE P, BARCELO A, MORO F, CLAUSTRE J, CHAYVIALLE JA, CUBER JC: Effects of neurotransmitters, gut hormones, inflammatory mediators on mucus discharge in rat colon. Am J Physiol 275: G1073-G1084, 1998.

REEVES PG, NIELSEN FH, FAHEY GC, JR. AIN-93 purified diets for laboratory rodents: final report of the American Institute of Nutrition ad hoc writing committee on the reformulation of the AIN-76A rodent diet. J Nutr 123: 1939-1951, 1993.

ROEDIGER WE: Utilization of nutrients by isolated epithelial cells of the rat colon. Gastroenterology 83: 424-429, 1982.

RONG M, ROSSI EA, ZHANG J, MCNEER RR, VAN DEN BRANDE JM, YASIN M, WEED DT, CAROTHERS CARRAWAY CA, THOMPSON JF, CARRAWAY KL: Expression, localization of Muc4/sialomucin complex (SMC) in the adult, developing rat intestine: implications for Muc4/SMC function. $J$ Cell Physiol 202: 275-284, 2005.

ROPERT A, CHERBUT C, ROZE C, LE QUELLEC A, HOLST JJ, FU-CHENG X, BRULEY DES VARANNES S, GALMICHE JP. Colonic fermentation, proximal gastric tone in humans. Gastroenterology 111: 289-296, 1996.

ROY CC, KIEN CL, BOUTHILLIER L, LEVY E: Short-chain fatty acids: ready for prime time? Nutr Clin Pract 21: 351-366, 2006.

SAKAMOTO K, MORI Y, TAKAGI H, IWATA H, YAMADA T, FUTAMURA N, SAGO T, EZAKI T, KAWAMURA Y, HIROSE H: Translocation of Salmonella typhimurium in rats on total parenteral nutrition correlates with changes in intestinal morphology, mucus gel. Nutrition 20: 372-376, 2004.

SAKATA T, SETOYAMA H: Local stimulatory effect of short-chain fatty acids on the mucus release from the hindgut mucosa of rats (Rattus norvegicus). Comp Biochem Physiol A Physiol 111: 429-432, 1995.

SCHAFER K: Analysis of short-chain-fatty acids from different intestinal samples by capillary gas-chromatography. Chromatographia 40: 550-556, 1995.

SEGAIN JP, RAINGEARD DE LA BLETIERE D, BOURREILLE A, LERAY V, GERVOIS N, ROSALES C, FERRIER L, BONNET C, BLOTTIERE HM, GALMICHE JP: Butyrate inhibits inflammatory responses through NFאB inhibition: implications for Crohn's disease. Gut 47: 397-403, 2000.

SHIMOTOYODOME A, MEGURO S, HASE T, TOKIMITSU I, SAKATA T: Short chain fatty acids but not lactate or succinate stimulate mucus release in the rat colon. Comp Biochem Physiol A Mol Integr Physiol 125: 525-531, 2000.

SWIDSINSKI A, LOENING-BAUCKE V, THEISSIG F, ENGELHARDT H, BENGMARK S, KOCH S, LOCHS H, DORFFEL Y: Comparative study of the intestinal mucus barrier in normal, inflamed colon. Gut 56: 343-350, 2007.

SZENTKUTI L, LORENZ K: The thickness of the mucus layer in different segments of the rat intestine. Histochem $J$ 27: 466-472, 1995. 
VAN DER SLUIS M, DE KONING BA, DE BRUIJN AC, VELCICH A, MEIJERINK JP, VAN GOUDOEVER JB, BULLER HA, DEKKER J, VAN SEUNINGEN I, RENES IB, EINERHAND AW: Muc2-deficient mice spontaneously develop colitis, indicating that MUC2 is critical for colonic protection. Gastroenterology 131: 117-129, 2006.

VERBURG M, RENES IB, MEIJER HP, TAMINIAU JA, BULLER HA, EINERHAND AW, DEKKER J: Selective sparing of goblet cells, Paneth cells in the intestine of methotrexate-treated rats. Am J Physiol 279: G1037G1047, 2000.

VESTERLUND S, KARP M, SALMINEN S, OUWEHAND AC: Staphylococcus aureus adheres to human intestinal mucus but can be displaced by certain lactic acid bacteria. Microbiology 152: 1819-1826, 2006.

WILLEMSEN LE, KOETSIER MA, VAN DEVENTER SJ, VAN TOL EA. Short chain fatty acids stimulate epithelial mucin 2 expression through differential effects on prostaglandin $E_{1}, E_{2}$ production by intestinal myofibroblasts. Gut 52: 1442-1447, 2003. 